\title{
Plasma Androgen Receptor in Prostate Cancer
}

\author{
Vincenza Conteduca ${ }^{1}, * \mathbb{C}$, Giorgia Gurioli ${ }^{2}$, Nicole Brighi $^{1}$, Cristian Lolli ${ }^{1}$, \\ Giuseppe Schepisi ${ }^{1} \oplus$, Chiara Casadei ${ }^{1}$, Salvatore Luca Burgio ${ }^{1}$, Stefania Gargiulo ${ }^{2}$, \\ Giorgia Ravaglia ${ }^{3}$, Lorena Rossi $^{1}$, Amelia Altavilla ${ }^{1}$, Alberto Farolfi ${ }^{1}{ }^{1}$, Cecilia Menna ${ }^{1}$, \\ Sarah Pia Colangione ${ }^{4}$, Mario Pulvirenti ${ }^{5}$, Antonino Romeo ${ }^{4}$ and Ugo De Giorgi ${ }^{1}$ \\ 1 Department of Medical Oncology, Istituto Scientifico Romagnolo per lo Studio e la Cura dei Tumori (IRST) \\ IRCCS, 47014 Meldola, Italy; nicole.brighi@irst.emr.it (N.B.); cristian.lolli@irst.emr.it (C.L.); \\ giuseppe.schepisi@irst.emr.it (G.S.); chiara.casadei@irst.emr.it (C.C.); salvatore.burgio@irst.emr.it (S.L.B.); \\ lorena.rossi@irst.emr.it (L.R.); amelia.altavilla@irst.emr.it (A.A.); alberto.farolfi@irst.emr.it (A.F.); \\ cecilia.menna@irst.emr.it (C.M.); ugo.degiorgi@irst.emr.it (U.D.G.) \\ 2 Biosciences Laboratory, Istituto Scientifico Romagnolo per lo Studio e la Cura dei Tumori (IRST) IRCCS, \\ 47014 Meldola, Italy; giorgia.gurioli@irst.emr.it (G.G.); stefania.gargiulo.94@gmail.com (S.G.) \\ 3 Unit of Biostatistics and Clinical Trials, Istituto Scientifico Romagnolo per lo Studio e la Cura dei \\ Tumori (IRST) IRCCS, 47014 Meldola, Italy; giorgia.ravaglia@irst.emr.it \\ 4 Radiotherapy Unit, Istituto Scientifico Romagnolo per lo Studio e la Cura dei Tumori (IRST) IRCCS, \\ 47014 Meldola, Italy; sarah.colangione@irst.emr.it (S.P.C.); antonino.romeo@irst.emr.it (A.R.) \\ 5 Department of Urology, Morgagni Pierantoni Hospital, 47121 Forli, Italy; mario.pulvirenti@auslromagna.it \\ * Correspondence: vincenza.conteduca@irst.emr.it
}

Received: 4 October 2019; Accepted: 31 October 2019; Published: 4 November 2019

\begin{abstract}
The therapeutic landscape of prostate cancer has expanded rapidly over the past 10 years, and there is now an even greater need to understand the biological mechanisms of resistance and to develop noninvasive biomarkers to guide treatment. The androgen receptor (AR) is known to be involved in the pathogenesis and progression of prostate cancer. Recently, highly sensitive next-generation sequencing and PCR-based methods for analyzing androgen receptor gene (AR) copy numbers $(\mathrm{CN})$ and mutations in plasma were established in cell-free DNA (cfDNA) of patients with castration-resistant prostate cancer (CRPC) treated with different drugs. The study of cfDNA holds great promise for improving treatment in CRPC, especially in the advanced stage of the disease. Recent findings showed the significant association of plasma $A R$ aberrations with clinical outcome in CRPC patients treated with AR-directed therapies, whereas no association was observed in patients treated with taxanes. This suggests the potential for using plasma $A R$ as a biomarker for selecting treatment, i.e., hormone therapy or chemotherapy, and the possibility of modulating taxane dose. In recent years, plasma $A R$ status has also been investigated in association with novel agents, such as ${ }^{177} \mathrm{Lu}$-PSMA radioligand therapy and PARP inhibitors. This review will focus on $A R$ testing in plasma that may have clinical utility for treatment selection in advanced prostate cancer.
\end{abstract}

Keywords: androgen receptor; prostate cancer; plasma DNA; biomarkers

\section{Introduction}

Prostate cancer is the most frequent cancer in men and the second most common cause of cancer-related death in Western countries [1]. The disease shows wide clinical variability and molecular heterogeneity. The androgen receptor (AR), a nuclear hormone receptor which, upon activation by androgens, translocates into the nucleus and binds to specific regulatory regions, plays a key role in the normal development of the prostate as well as in the pathogenesis of prostate cancer. The majority of androgen-independent or hormone refractory prostate cancers express AR, thus making it an important therapeutic target in all tumor stages ranging from early to the more advanced disease [2]. 
The majority of hormone-naïve prostate cancer (HNPC) patients characterized by non-castrate testosterone levels who undergo androgen deprivation treatment (ADT) may become castrationresistant (CRPC). CRPC is defined as radiographic progression and/or increase in serum prostate-specific antigen (PSA) levels despite a low testosterone concentration $(<50 \mathrm{ng} / \mathrm{mL})[3,4]$ Despite therapeutic advances in the last two decades, these patients still show a low median survival ranging from approximately 18 to 36 months [5].

There are several therapeutic options available for prostate cancer, including radiotherapy, ADT, second generation AR-signaling inhibitors, chemotherapy, and bone-targeted agents. Numerous trials are also ongoing for the approval of novel targeted drugs (Figure 1).

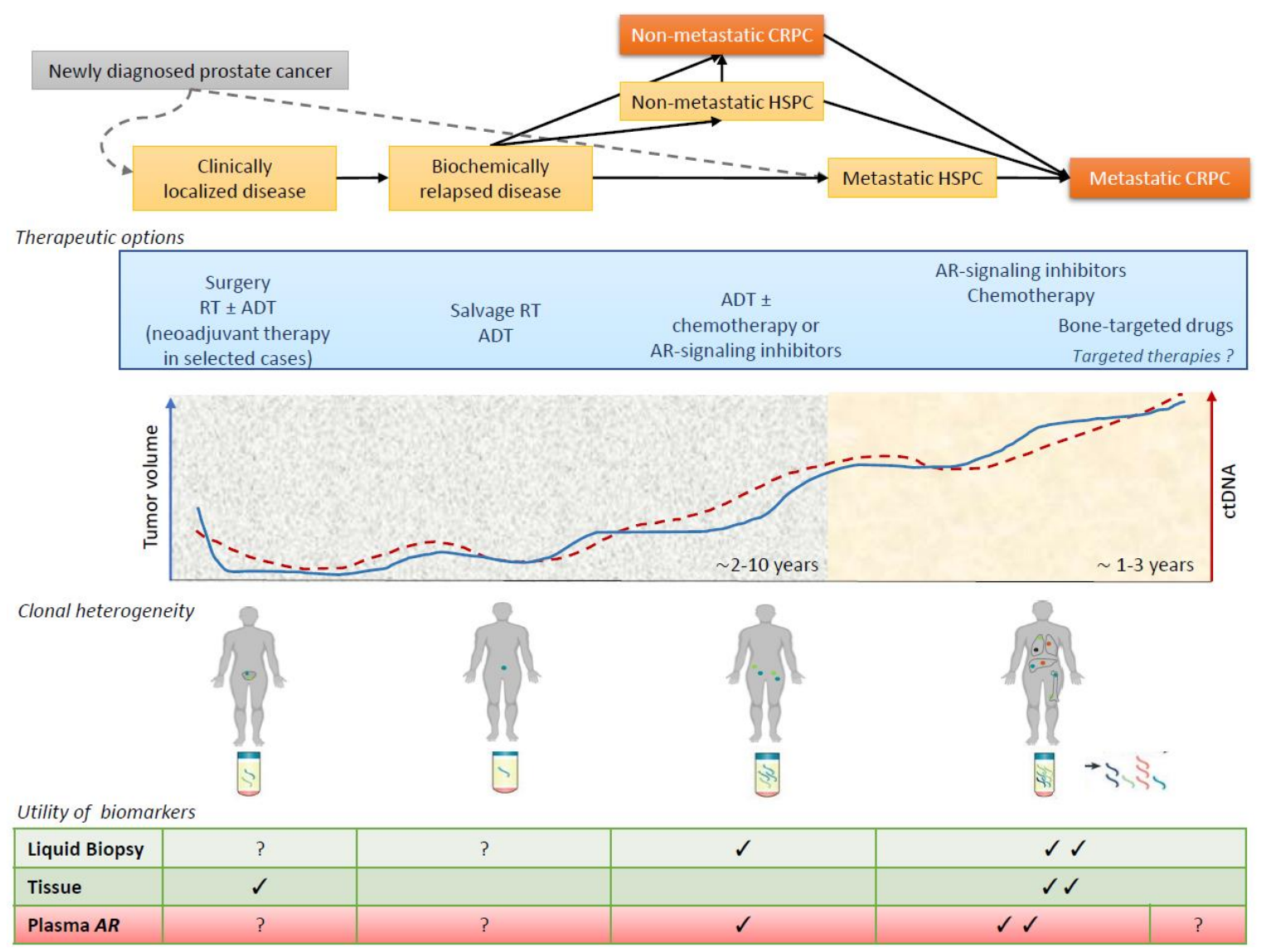

Figure 1. The role of biomarker tools and plasma $A R$ status in different clinical states of prostate cancer. A clinical states framework for clinical practice, clinical research, and biomarker tools in prostate cancer with a graphical representation of tumor burden, plasma DNA levels, clonal heterogeneity, and utility of plasma $A R$ status over time and in response to therapy. Abbreviations: ADT, androgen deprivation therapy; $\mathrm{AR}$, androgen receptor; $\mathrm{CRPC}$, castration-resistant prostate cancer; ctDNA, circulating tumor DNA; HSPC, hormone-sensitive prostate cancer; RT, radiotherapy.

In this paper, we review the literature on the role of AR detected in the plasma of patients with prostate cancer as a novel prognostic and predictive biomarker in different settings of prostate cancer.

\section{Clinical Prognostic Factors in Prostate Cancer}

Currently, prostate cancer treatment decisions (curative treatments or active surveillance) in the setting of localized disease are still based almost exclusively on histological architecture (Gleason score) [6], prostate-specific antigen (PSA) levels [6] and local disease state (TNM) [7], with little attention paid to molecular features, except for some genomic tests using tissue biopsy (Prolaris, OncotypeDx, and Decipher) available for men with localized prostate cancer [8-10] and there is early metastasis 
prediction model based on genomic expression in the primary tumor which could be helpful for identification of aggressive prostate cancer [11]. Prolaris is a panel of cell cycle progression genes that can be measured in both untreated and previously treated patients [8]. OncotypeDx predicts the risk of disease recurrence at radical prostatectomy for men with low-to-intermediate risk prostate cancer [9]. Decipher provides information on genome-wide RNA expression for newly diagnosed patients which can be used to predict the risk of metastasis in men with adverse pathology at radical prostatectomy. Additionally, these assays could help to imrpove prognostic risk stratification to aid treatment decisions [10]. However, they should be prospectively validated, especially with respect to their clinical utility and impact on the cost of localized prostate cancer care.

During disease evolution, further clinical factors are used for prognostication and risk stratification. In patients diagnosed with nonmetastatic disease, baseline PSA levels, PSA velocity, and PSA doubling time are associated with clinical outcome and can be used to select patients whose follow-up requires imaging studies [12].

Although there is no universally accepted prognostic classification for patients with metastatic HNPC (mHNPC), a recent study [13] identified time of metastatic presentation and disease volume as prognostic variables for mHNPC patients treated with ADT. In the last few years, the therapeutic landscape for mHNPC has substantially changed, with the addition of docetaxel or abiraterone acetate to ADT in selected cases based on tumor (number and site of metastasis) and clinical patient characteristics [14-17]. However, predictive biomarkers are also warranted to facilitate treatment decision-making (single or combination) in HNPC patients.

Several prognostic nomograms, especially in CRPC, have been developed to predict overall survival (OS) and to assess risk stratification in clinical trials [5,18-20]. Following a number of recent trials focusing on the treatment of mHNPC [14-16] and the introduction of abiraterone or enzalutamide as first-line treatment in most mCRPC patients based on the results of COU-AA-302 and PREVAIL studies [21,22], new nomograms are currently being developed in this earlier setting.

One important aspect to consider in the evaluation of treatment outcome is the biological heterogeneity of prostate malignancy. Thus, disease stratification based on molecular signatures is warranted in prostate cancer, as it has also been shown to aid the prognostic evaluation and management of other epithelial cancers such as breast cancer [23].

\section{Molecular Factors in Driving Castration-Resistant Prostate Cancer (CRPC) Emergence}

Over the years, many studies have consistently shown that the majority of CRPCs are still dependent on AR signaling, which may also play a role in the transition from early to advanced disease, even at low concentrations of androgens. One of the most important objectives of recent molecular studies has been to identify synergistic factors which, together with AR, are involved in prostate cancer progression.

The phase III CALGB 90203 trial [24] aimed to explore the molecular alterations associated with chemotherapy/hormone therapy in the neoadjuvant setting. Targeted DNA sequencing ( $n=72$ genes) and expression profiling using NanoString platform ( $\mathrm{n}=163$ genes) were performed on prostatectomy-derived tissue specimens of 52 patients enrolled in the study. The most frequent alterations were TMPRSS2-ERG fusion (61.5\%), TP53 mutation or deletion (21.1\%), PTEN deletion $(11.5 \%)$, FOXA1 (11.5\%), and SPOP $(7.7 \%)$ mutation, with no significant enrichment in post-treated specimens.

In this study [24], no $A R$ aberration was observed in the neoadjuvant setting, probably because $A R$ amplification and mutations are typically later events in the process of prostate cancer progression (present in $60 \%$ of metastatic disease) [25,26]. However, some studies [27-29] have shown that AR signaling may also be relevant at early time-points and potentially drive response and resistance to therapy, probably through mechanisms different to those of later AR reactivation in CRPC. Further studies are warranted in this setting (Figure 1). Beltran et al. [24] observed an upregulation of both $\mathrm{AR}$ and a specific variant of AR (AR-V7) in the group treated with neoadjuvant therapy comprising 
docetaxel and ADT. The ratio of AR-V7 to wild-type AR was also comparable in the untreated cases. These findings support the hypothesis that the activity of AR and/or alternative transcriptional enhancers may persist, providing the basis for subsequent castration resistance.

Lastly, genomic and transcriptomic analysis of CALGB 90203 trial [24] demonstrated the upregulation of both neuroendocrine and plasticity genes (such as RB1, TP53, and MYC) [30-32], and the downregulation of AR target genes including the TMPRSS2-ERG fusion transcript in post-treatment tissue specimens. Thus, neoadjuvant treatment may shape the clonal architecture of prostate cancer with involvement of lineage plasticity and neuroendocrine differentiation, not only in mCRPC but also in early disease, leading to an early adaptive response or acquired resistance, as previously shown in patient-derived xenograft (PDX) models [33,34].

The ability of prostate cells to reversibly alter their lineage identity is responsible for phenotypic plasticity, which is now widely acknowledged as a mechanism of progression in CRPC, driving resistance to next-generation $\mathrm{AR}$ signaling inhibitors and leading to the acquisition of neuroendocrine features in approximately $20-25 \%$ of cases [35].

Similarly, the study by Sowalsky et al. [36] on radical prostatectomy tissue from 18 men treated with neoadjuvant ADT and abiraterone revealed the phenomenon of lineage plasticity, underlining the presence of RB1 genomic loss as an early "hit" in the onset of mCRPC. Consequently, in localized primary tumors, we could identify tumors at high-risk of aggressiveness, after which a so comprehensive molecular analysis could help to identify the best therapeutic strategy for eliminating the aggressive subclones in both neoadjuvant and adjuvant settings.

\section{Biomarker Tools in Prostate Cancer}

Recent genomic studies have identified distinct molecular subclasses, providing a valuable insight into inter- and intra-patient heterogeneity in different settings of prostate cancer [37-42] and showing that genetic changes associated with aggressive disease, when present in early tumors, herald the onset of early biochemical relapse, castration resistance or distant disease progression. However, the majority of these studies evaluated the entire prostate gland to obtain a comprehensive molecular landscape, but this is not always feasible as prostate cancer is often multifocal $[43,44]$ and sometimes also genomically heterogeneous [45], especially in the later stages of the disease, e.g., castration-resistant tumors. Several whole-exome and transcriptome sequencing studies of metastatic tumor biopsies obtained at a single time-point in this setting provided an interesting insight into the complexity and distribution of genomic aberrations $[40,46,47]$ and, given that the procurement of multiple, sequential tumor biopsies from prostate cancer patients is challenging, defining a comprehensive assessment of the changes occurring over time requires more innovative approaches. Consequently, the introduction of liquid biopsies such as circulating tumor cells (CTCs) and circulating tumor DNA (ctDNA) has led to a better monitoring of tumor clone dynamics and a more detailed study of molecular alterations involved in the malignant evolution of prostate cancer (Figure 2).

CTCs in the peripheral blood originate from the primary or metastatic tumor and are involved in the formation of metastasis [48]. Several randomized clinical trials have shown that the enumeration of CTCs is a strong predictive and prognostic biomarker before starting therapy [49-52] and during treatment $[53,54]$. Consequently, PCWG3 guidelines [4] recommended the use of CTC enumeration.

Molecular alterations in androgen receptor (AR) on CTCs have been investigated in CTCs to assess their potential as predictors of resistance to treatment. Antonarakis et al. reported an association between AR splice variant-7 (AR-V7) detected in CTCs and resistance to AR-directed therapies in patients with mCRPC [55], but no significant correlation with taxane therapy [56,57]. Recently, a real-time CTC-based assay of nuclear AR expression in the CTCs of CRPC patients was developed using CellSearch System [58]. In addition, phenotypic heterogeneity of CTCs has been shown to inform clinical decision-making between AR-signaling inhibitors and taxanes in mCRPC. 

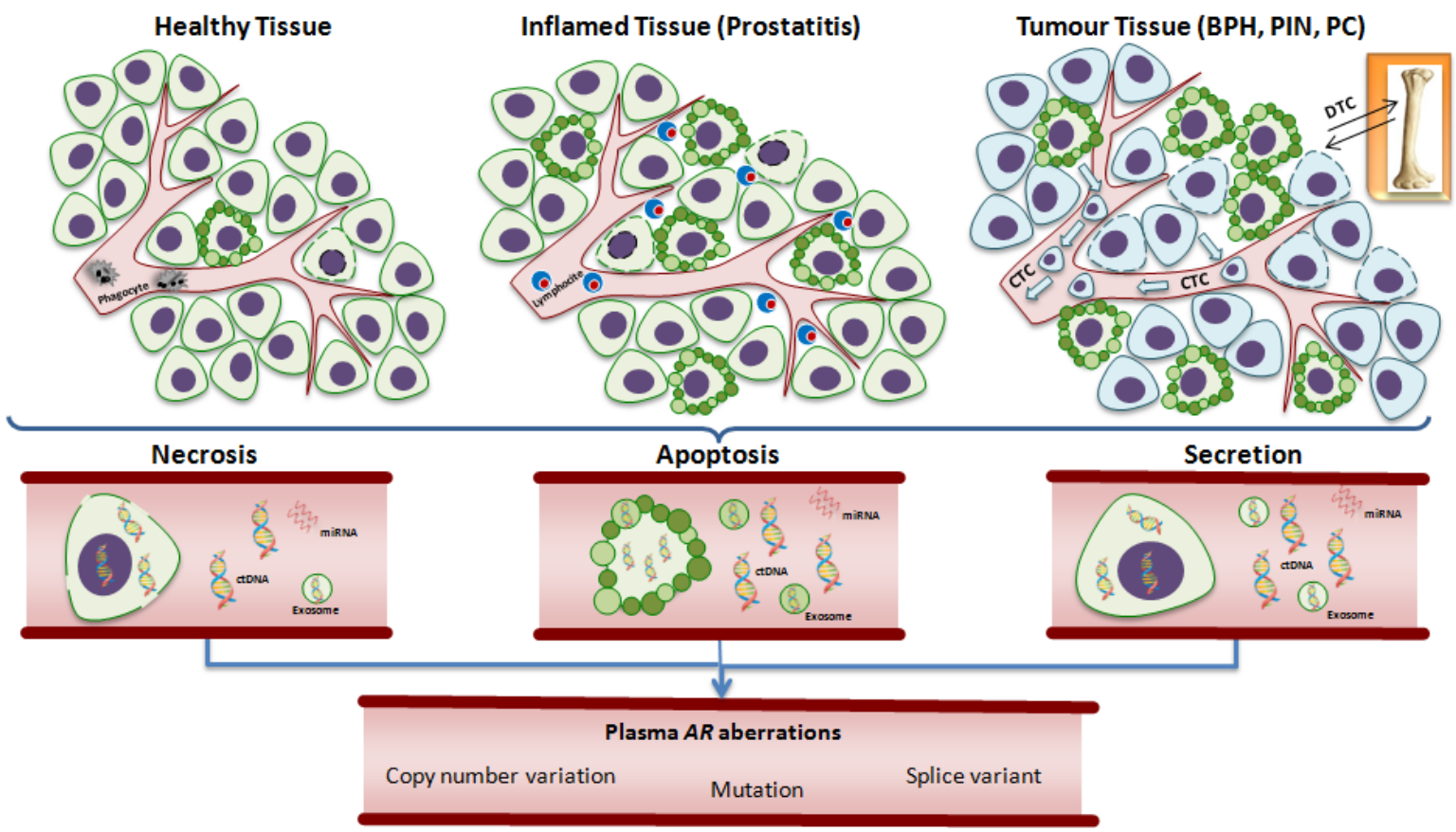

Figure 2. Biology of circulating free DNA. Circulating free DNA (plasma DNA) is released from the cells of healthy, inflamed, or tumor tissue undergoing apoptosis or necrosis, or, more rarely, from living cancer cells that actively release DNA into the circulation because of oncogenic properties. Certainly, levels of plasma DNA are also under the control of the activity of infiltrating phagocytes that usually clear apoptotic and necrotic debris and pro-apoptotic cytokines released by inflammatory cells (e.g., lymphocytes) or cancer cells. Circulating DNA may also be released by CTCs shed by the tumor and by DTC into bone marrow. The analysis of plasma DNA, together with other circulating nucleic acids in the bloodstream, such as miRNA and exosomes, has led to the identification of several genetic and epigenetic alterations of tumor, including circulating aberrations of androgen receptor such as copy number variation, mutations and splice variants. Abbreviations: $\mathrm{AR}$, androgen receptor; $\mathrm{BPH}$, benign prostatic hyperplasia; ctDNA, circulating tumor DNA; CTC, circulating tumor cell; DTC, disseminated tumor cell; miRNA, microRNA; PC, prostate cancer; PIN: prostatic intraepithelial neoplasia.

Additional molecular tools evaluating treatment response are also being developed, including the analysis of ctDNA [59-66].

Circulating cell-free DNA (cfDNA) has been detected in the plasma of healthy subjects and men with benign [inflammation, benign prostatic hyperplasia (BPH)] or malignant prostate diseases. Nevertheless, ctDNA, which represents less than $3.0 \%$ of total cfDNA, is about three to four times higher in cancer patients than in healthy individuals [67] (Figure 2).

Plasma ctDNA analysis is particularly useful for detecting the evolving therapeutic landscape of $\mathrm{mCRPC}$ and for monitoring unpredictable cross-resistance phenomena among agents targeting different pathways such as AR signaling (e.g., enzalutamide and abiraterone) $[21,22,68,69]$, taxane-based chemotherapies [70,71], DNA repair mechanisms [e.g., poly (ADP-ribose) polymerase (PARP) inhibitors] in patients with defects in homologous recombination genes [72], and PI3K/AKT pathway inhibition in PTEN-deleted patients [73]. Consequently, there is an urgent need for real-time and practical tumor biomarkers to guide treatment selection and, for this purpose, ctDNA profiling, theoretically available for any patient and at different time-points, could provide a complete overview of genomic information.

The estimation of ctDNA fraction has also been acknowledged as a predictor of prognosis and treatment resistance in $\mathrm{MCRPC}$, whereas there is only preliminary evidence of this in HNPC. Recently, Chi et al. did not observe an increase in the acquisition of AR aberrations (ARV-7, AR amplification, AR ligand binding domain mutations) from cell-free DNA and cfRNA using next-generation sequencing and PCR, respectively, in mHNPC patients treated with apalutamide plus ADT [74]. 
Moreover, ctDNA tumor fraction may be underestimated in some cases because of the emergence of lesions not included in the targeted gene custom panel used for estimating tumor content.

Despite the fact that ctDNA fraction can also be considered as a useful prognostic biomarker in castration-resistant disease, it should be borne in mind that plasma DNA sequencing is characterized by several limitations involving costs, genome coverage and sensitivity to low ctDNA fraction. Nevertheless, the main limitation of these recent studies on cfDNA concentration remains its inability to specifically quantitate tumor-derived cfDNA fraction in plasma DNA.

However, in general, leveraging plasma specimens collected from different stages of prostate cancer may improve the characterization of key targets for prostate cancer, such as AR, in the real-time and genomic sub-classification of CRPC.

\section{Detection of Androgen Receptor in Plasma}

The persistent activation of the AR pathway, including AR gene amplification and mutations, and the generation of truncated splice variants lacking the ligand-binding domain (LBD) [75], represent a fundamental mechanism of the emergence of castration resistance. The detection of molecular aberrations in CRPC metastatic sites $[40,76]$ was performed with the difficulty of obtaining tissue material amenable to genomic studies and patient consent, which is handled differently in different countries. In prostate cancer, plasma DNA analysis is being increasingly used to identify molecular aberrations but it is not yet a validated test in clinical practice such as and testing of plasma epidermal growth factor receptor (EGFR) mutations, which represents one of current molecular tools in oncology approved by the Food and Drug Administration (FDA) for the treatment selection of EGFR tyrosine kinase inhibitors in mutant lung cancer patients [77]. Recently, the presence of AR amplification and point somatic mutations detected in plasma has been also investigated and associated with a worse outcome in CRPC patients treated with hormonal therapies [59-66].

Plasma $A R$ aberrations have been studied using targeted-next generation sequencing (NGS). In several studies a customized AmpliSeq targeted gene panel including $A R$ and other gene targets was sequenced on an Ion Torrent Personal Genome Machine or Proton [59,64]. Subsequently, a computational analysis assessed ctDNA fraction, $A R$ copy number variation and point mutation detection (with a sensitivity of 98-99\%). Recently, our group identified a multiplex digital droplet PCR (ddPCR) to assess AR copy number and mutations in plasma cfDNA [64]. Different reference genes (NSUN3, ElF2C1, and AP3B1), and ZXDB at Xp11.21 as a control gene were used to estimate copy number of $X$ chromosome. Each AR CN estimation per reference gene was within two standard deviations from the average $\mathrm{AR} \mathrm{CN}$, considering all reference genes and with a high correlation among the individual reference genes. AR mutation detection assays were performed for the AR mutations 2105T > A (p.L702H), 2632A > G (p.T878A) and 2629T > C (p.F877L), with a limit of detection of 1-2\% using an input of 2-4 ng of DNA. Conteduca et al. observed a correlation between NGS and ddPCR results for AR copy number and mutations, reporting a strong agreement in both cases (Limits of agreement: mean difference $-0.02,95 \%$ confidence intervals (CI) -2.45 to 2.41 , and mean difference $p<0.001,95 \%$ CI, -0.015 to 0.016 , respectively) [64].

Other more common methods available for detecting ctDNA and analyzing plasma AR status are summarized in Table 1. 
Table 1. Most common methods used to detect circulating tumor DNA (ctDNA) and analyse plasma androgen receptor (AR) status.

\begin{tabular}{|c|c|c|}
\hline Method & Advantages & Limitations \\
\hline \multicolumn{3}{|l|}{ Focused } \\
\hline \multicolumn{3}{|l|}{ Quantitative real time PCR } \\
\hline Fluorescence- labeled PCR & \multirow{8}{*}{$\begin{array}{l}\text { Variable sensitivity with detection } \\
\text { limit }<1 \%(0.01 \% \text { for digital PCR, } \\
\text { PAP-A and BEAMing) } \\
\text { Easy and rapid to use. } \\
\text { Less expensive. } \\
\text { Multiplex ddPCR can } \\
\text { simultaneous screening for } \\
\text { multiple mutations from the same } \\
\text { sample }\end{array}$} & \multirow{8}{*}{$\begin{array}{l}\text { Necessary known hotspots in } \\
\text { selected genes (or single probes for } \\
\text { rare variants designed on a } \\
\text { 'personalized' basis). }\end{array}$} \\
\hline Nested real time PCR & & \\
\hline ARMS-Scorpion PCR & & \\
\hline PAP-A & & \\
\hline BEAMing & & \\
\hline ddPCR & & \\
\hline Microfluidic digital PCR & & \\
\hline Mass spectrometry & & \\
\hline \multicolumn{3}{|l|}{ Targeted } \\
\hline PARE & \multirow{5}{*}{$\begin{array}{l}\text { High depth and sensitivity of } \\
\text { analysis with detection limit } 2 \% \\
(0.1 \% \text { and } 0.01 \% \text { for Tam-Seq and } \\
\text { CAPP-Seq, respectively). } \\
\text { De novo mutation identification. } \\
\text { More comprehensive analysis } \\
\text { across wider genomic regions }\end{array}$} & \multirow{5}{*}{$\begin{array}{l}\text { Very costly } \\
\text { Requirement for high-quality } \\
\text { DNA Extensive data analysis } \\
\text { requiring a dedicated } \\
\text { bioinformatician }\end{array}$} \\
\hline Tam-Seq & & \\
\hline Safe-Seq & & \\
\hline CAPP-Seq & & \\
\hline Ion-Ampliseq & & \\
\hline \multicolumn{3}{|l|}{ Broad } \\
\hline WES/WGS & $\begin{array}{l}\text { High sensitivity with detection } \\
\text { limits } 1-5 \% \text {. } \\
\text { Characterization a large spectrum } \\
\text { of the genome, without the need to } \\
\text { focus on predefined or existing } \\
\text { alterations. } \\
\text { More in-depth interrogation of } \\
\text { multiple regions (WES > WGS) }\end{array}$ & $\begin{array}{l}\text { Very costly } \\
\text { Requirement for high-quality } \\
\text { DNA Extensive data analysis } \\
\text { requiring a dedicated } \\
\text { bioinformatician. } \\
\text { To accurately detect clinical } \\
\text { mutations, a 100-to 200-fold } \\
\text { sequencing coverage (number of } \\
\text { times the genome is sequenced) } \\
\text { may be needed, which are both } \\
\text { time and cost prohibitive. } \\
\text { Low sensitivity for the } \\
\text { identification of copy number } \\
\text { variation (WES) }\end{array}$ \\
\hline
\end{tabular}

Abbreviations: ARMS, amplification refractory mutation system; BEAMing, beads, emulsion, amplification, magnetics; CAPP-Seq, cancer personalized profiling by deep sequencing; HCC, hepatocellular cancer; NSCLC, non-small cell lung cancer; PAP-A, pyrophosphorolysis-activated polymerization-allele-specific amplification; PARE, personalized analysis of rearranged ends; Safe- SeqS, safe-sequencing system; TAm-Seq, tagged amplicon deep sequencing; WGS, whole genome sequencing; WES, whole exome sequencing.

\section{Plasma Androgen Receptor (AR) and Hormonal Treatments}

AR gene aberrations have been shown to be uncommon in the early stages of prostate cancer, but very frequent in CRPC. In fact, NGS- and PCR-based studies have focused in particular on AR copy number in advanced disease, mainly in a post-docetaxel setting. Romanel et al. [59] sequenced 274 plasma samples from 97 CRPC patients treated with abiraterone, reporting that plasma $A R$ gain and point mutations were mutually exclusive, and that $A R$ copy number was unchanged during abiraterone treatment. Moreover, the onset of T878A or L702H AR amino acid changes was reported in $13 \%$ of samples at progression on abiraterone. The association between plasma $A R$ aberrations and outcome was very interesting, revealing a letter reduction in PSA in AR-aberrant patients than in AR-normal patients, and significantly shorter OS [hazard ratio (HR) 7.33, 95\% CI 3.51-15.34, $p=1.3 \times 10^{-9}$ ) 
and progression-free survival (PFS) (HR 3.73, 95\% CI 2.17-6.41, $p=5.6 \times 10^{-7}$ ). Subsequently, Conteduca et al. assessed the role of plasma $A R$ not only in a post-docetaxel group, but also in a chemotherapy-naïve setting [64]. A primary cohort including 73 chemotherapy-naïve and 98 post-docetaxel patients treated with enzalutamide or abiraterone were evaluated between January 2011 and June 2016 and independently recruited to biomarker protocols at the Royal Marsden (London, UK) or IRST IRCCS (Meldola, Italy). Ten (14\%) pre-chemotherapy and $33(34 \%)$ post-docetaxel showed $A R$ gain. Eight (11\%) post-docetaxel but no chemotherapy-naïve abiraterone-treated patients were $A R$ mutant. Chemotherapy-naïve and post-docetaxel $A R$-gained patients had a worse outcome (OS: $\mathrm{HR}=3.98,95 \%$ CI 1.74-9.10, $p<0.001$ and HR $=3.81,95 \%$ CI 2.28-6.37, $p<0.001$, respectively, and PFS: $\mathrm{HR}=2.18,95 \%$ CI 1.08-4.39, $p=0.03$, and HR $=1.95,95 \%$ CI 1.23-3.11, $p=0.01$, respectively). Patients with $A R$ mutations also had a significantly shorter OS $(\mathrm{HR}=3.26,95 \% \mathrm{CI} 1.47$-not reached, $p=0.004)$. These data were validated in a secondary cohort of 94 chemotherapy-naïve patients treated with enzalutamide in 16 institutions in the PREMIERE trial (NCT02288936). Eleven (12\%) had AR gain. AR-gained patients had worse biochemical PFS (HR $=4.33,95 \%$ CI 1.94-9.68, $p<0.001)$, radiographic PFS (HR $=8.06,95 \%$ CI 3.26-19.93, $p<0.001)$, OS (HR = 11.08, 95\% CI 2.16-56.95, $p=0.004)$. Subsequently, plasma $A R$ was associated with different prognostic/predictive factors to identify additional mechanisms of resistance to AR-directed therapies.

After establishing the prognostic/predictive role of plasma AR gain in CRPC patients receiving AR signaling inhibitors, Conteduca et al. evaluated its association with other biomarkers, such as choline uptake in 18F-fluorocholine positron emission tomography/computed tomography (FCH-PET/CT) [78,79]. Eighty post-docetaxel CRPC patients treated with abiraterone $(n=47)$ or enzalutamide $(\mathrm{n}=33)$ were evaluated and, a robust correlation was observed between $A R$ gain and some FCH-PET/CT parameters (tumor lesion activity and metabolic tumor volume), both of which can be considered as independent factors of PFS and OS in multivariate analysis.

An additional association was observed between plasma AR and serum concentration of chromogranin A (CGA) [80,81], which is considered a marker of neuroendocrine differentiation (NED), an alternative mechanism of resistance to hormonal treatments. Neuroendocrine prostate cancer (NEPC) is a rare, lethal subtype of prostate cancer characterized by AR-independence, reduced PSA level, and usually by the expression of neuroendocrine markers, such as CGA, synaptophysin, and neuron-specific enolase (NSE) [82]. A recent study [83] showed that patients with adenocarcinoma harboring specific clinical and molecular features (e.g., liver metastases, slight increase in PSA, high levels of neuroendocrine markers, TP53 or RB1 alterations) before a confirmed clinical diagnosis of therapy-related NEPC (especially after abiraterone or enzalutamide treatment) were considered to have a high risk of developing NED. Thus, Conteduca et al. assessed the impact of combining serum CGA level and plasma AR copy number by ddPCR on the outcome of 256 CRPC patients treated with AR-directed therapies [84]. Plasma $A R$ gain and high pre-treatment levels of serum and LDH were viewed as independent predictors of PFS and OS, suggesting the utility of assessing serum CGA before starting abiraterone or enzalutamide treatment together with plasma $A R$ status to identify a subgroup of CRPC patients who are not likely to respond to AR-directed agents but have no AR aberrations.

\section{Plasma Androgen Receptor (AR) and Chemotherapy}

Docetaxel and cabazitaxel represent the most widely used chemotherapies for patients with mCRPC. They have a similar function, preventing mitosis and microtubule-dependent trafficking and eliciting apoptosis. In addition, they may block nuclear translocation and AR activity [85]. The role of plasma $A R$ gain in patients treated with taxanes was explored in two multi-institutional studies $[86,87]$ that performed a pooled analysis of AR status, determined by droplet digital PCR, on pre-treatment plasma samples. The first biomarker study evaluated the association between plasma $A R$ and OS/PFS and PSA response rate in 163 docetaxel-treated patients, reporting only a significant shorter OS in $A R$-gained patients ( $\mathrm{HR}=1.61,95 \%$ CI 1.08-2.39, $p=0.018$ ). In addition, the same authors studied the interaction between plasma $A R$ and treatment type in 73 patients of the 
abiraterone/enzalutamide-treated group (after incorporating updated data from their prior study [64]) and 115 first-line docetaxel patients. In first-line therapy group, findings suggested that $A R$-normal patients could benefit from hormonal treatment, while plasma $A R$-gained subjects had a better response to docetaxel. Similar results were observed for second-line therapy mCRPC patients, with a meaningful treatment interaction between plasma $A R$ and cabazitaxel vs. AR-directed therapies for OS $(p=0.041)$. In addition, Conteduca et al. performed an exploratory analysis of an AR-gained cabaxitaxel cohort, revealing that these patients, treated with an initially reduced dose of cabazitaxel, had a significantly shorter OS/PFS and would probably need a standard initial dose of cabazitaxel. Plasma AR status was shown to have a potential clinical utility in patients being considered for treatment with taxanes.

\section{Plasma Androgen Receptor (AR) and Novel Drugs}

In a phase 2 clinical trial (NCT03454750) of mCRPC patients treated with ${ }^{177}$ Lu-PSMA-617, plasma $A R$ gene status was also assessed in association with clinical outcome [88]. Early progressive disease was reported in 17 (42.5\%) of the 40 patients (12 of $15(80 \%)$ with $A R$ gene gain and 5 of $25(20 \%)$ with $A R$ normal $(p=0.0002)$ ). The OR for patients with early disease progression and $A R$ gain was $16.00,95 \%$ CI 3.23-79.27, $p=0.0007$. These preliminary data suggest that plasma $A R$ status determined by ddPCR could be useful to identify mCRPC patients resistant to ${ }^{177} \mathrm{Lu}-\mathrm{PSMA}-617$.

Recently, preclinical data indicated a synergy between olaparib and androgen pathway inhibitors. Specifically, a randomized, double-blind, placebo-controlled, phase 2 trial assessed the efficacy of olaparib plus the androgen pathway inhibitor abiraterone in patients with mCRPC regardless of HRR mutation status, results showing the clinical benefit of the combination compared with abiraterone alone [89]. Plasma AR status could thus help to increase clinical benefit in a broader population of mCRPC.

In addition, recent studies assessed the role of AR mutations, e.g., F877L and T878A, in the resistance to next-generation AR-directed therapies, such as apalutamide [90] and darolutamide [91]. The phase I/II study ARN-509-001 [90] used the sensitive BEAMing assay to detect AR mutations in plasma DNA in apalutamide-treated nonmetastatic CRPC and mCRPC patients. However, the overall frequency of $A R$ mutations was very low, underlining that they could be not considered as a helpful biomarker to identify acquired resistance to apalutamide.

Recent preclinical evidence [92] has also emerged of the activity of darolutamide in enzalutamide-treated CRPC, revealing the activity of darolutamide to significantly inhibit the transcriptional action of F877L, H875Y/T878A, F877L/T878A, and T878G AR mutants, which transform enzalutamide into a partial agonist. These preliminary preclinical results could be corroborated in ctDNA assays are capable of detecting AR mutants sensitive to darolutamide or other novel hormonal drugs, in a precision oncology setting.

\section{Conclusions}

The current therapeutic and molecular landscape of prostate cancer is rapidly changing and has led to novel findings not only in CRPC, but also in earlier stages of the disease. In this context, the identification of predictive and prognostic biomarkers is essential, and it is possible thanks to the use of plasma DNA to monitor tumor dynamics and treatment outcome. In prostate cancer, plasma $A R$ status, given its role in patients treated with different drugs, could become an important predictive biomarker to guide treatment selection in $\mathrm{MCRPC}$, along with other factors such as PSA level. Indeed, plasma $A R$ status has also recently been assessed in the context of a novel potential prognostic index model for survival including clinical, imaging, and molecular factors [93].

In conclusion, the integration of different biomarker strategies, including genomics, with plasma $A R$ status in prostate cancer, could substantially improve prognostication and stratification of these patients. A prospective evaluation of plasma $A R$ as a biomarker of treatment selection is warranted with a possible validation cohort, and there is an urgent need to assess the utility of plasma $A R$ not only in advanced patients, but also in those with earlier stages of the disease. 
Funding: The authors received no specific funding for this work.

Acknowledgments: We thank Gráinne Tierney for editorial assistance.

Conflicts of Interest: V.C. has received speaker honoraria or travel support from Astellas, Janssen-Cilag, and Sanofi-Aventis, and has received consulting fee from Bayer. U.D.G. has served as consultant/advisory board member for Astellas, Bayer, BMS, Ipsen, Janssen, Merck, Pfizer, Sanofi, and has received travel support from BMS, Ipsen, Janssen, Pfizer, and has received research funding from AstraZeneca, Roche, Sanofi (Inst). No potential conflicts of interest were disclosed by the other authors.

\section{References}

1. Siegel, R.L.; Miller, K.D.; Jemal, A. Cancer statistics, 2019. CA Cancer. J. Clin. 2019, 69, 7-34. [CrossRef] [PubMed]

2. Davies, A.; Conteduca, V.; Zoubeidi, A.; Beltran, H. Biological evolution of castration-resistant prostate cancer. Eur. Urol. Focus. 2019, 5, 147-154. [CrossRef] [PubMed]

3. Scher, H.I.; Halabi, S.; Tannock, I.; Morris, M.; Sternberg, C.N.; Carducci, M.A.; Eisenberger, M.A.; Higano, C.; Bubley, G.J.; Dreicer, R.; et al. Design and endpoints of clinical trials for patients with progressive prostate cancer and castrate levels of testosterone: Recommendations of the prostate cancer clinical trials working group. J. Clin. Oncol. 2008, 26, 1148-1159. [CrossRef] [PubMed]

4. Scher, H.I.; Morris, M.J.; Stadler, W.M.; Higano, C.; Basch, E.; Fizazi, K.; Antonarakis, E.S.; Beer, T.M.; Carducci, M.A.; Chi, K.N.; et al. Trial design and objectives for castration-resistant prostate cancer: Updated recommendations from the prostate cancer clinical trials working group 3. J. Clin. Oncol. 2016, 34, 1402-1418. [CrossRef]

5. Halabi, S.; Lin, C.Y.; Kelly, W.K.; Fizazi, K.S.; Moul, J.W.; Kaplan, E.B.; Morris, M.J.; Small, E.J. Updated prognostic model for predicting overall survival in first-line chemotherapy for patients with metastatic castration-resistant prostate cancer. J. Clin. Oncol. 2014, 32, 671-677. [CrossRef]

6. Gleason, D.F.; Mellinger, G.T. Prediction of prognosis for prostatic adenocarcinoma by combined histological grading and clinical staging. J. Urol. 1974, 111, 58-64. [CrossRef]

7. Catalona, W.J.; Richie, J.P.; Ahmann, F.R.; Hudson, M.A.; Scardino, P.T.; Flanigan, R.C.; DeKernion, J.B.; Ratliff, T.L.; Kavoussi, L.R.; Dalkin, B.L.; et al. Comparison of digital rectal examination and serum prostate specific antigen in the early detection of prostate cancer: Results of a multicenter clinical trial of 6, 630 men. J. Urol. 1994, 151, 1283-1290. [CrossRef]

8. Sobin, L.H.; Gospodarowicz, M.; Wittekind, C. TNM Classification of Malignant Tumors, 7th ed.; UICC International Union Against Cancer; Wiley-Blackwell: New York, NY, USA, 2009.

9. Oderda, M.; Cozzi, G.; Daniele, L.; Sapino, A.; Munegato, S.; Renne, G.; De Cobelli, O.; Gontero, P. Cell-cycle progression-score might improve the current risk assessment in newly diagnosed prostate cancer patients. Urology 2017, 102, 73-78. [CrossRef]

10. Brand, T.C.; Zhang, N.; Crager, M.R.; Maddala, T.; Dee, A.; Sesterhenn, I.A.; Simko, J.P.; Cooperberg, M.R.; Srivastava, S.; Rosner, I.L.; et al. Patient-specific meta-analysis of 2 clinical validation studies to predict pathologic outcomes in prostate cancer using the 17-gene genomic prostate score. Urology 2016, 89, 69-75. [CrossRef]

11. Erho, N.; Crisan, A.; Vergara, I.A.; Mitra, A.P.; Ghadessi, M.; Buerki, C.; Bergstralh, E.J.; Kollmeyer, T.; Fink, S.; Haddad, Z.; et al. Discovery and validation of a prostate cancer genomic classifier that predicts early metastasis following radical prostatectomy. PLoS ONE 2013, 8, e66855. [CrossRef]

12. Mateo, J.; Fizazi, K.; Gillessen, S.; Heidenreich, A.; Perez-Lopez, R.; Oyen, W.J.G.; Heidenreich, A.; Perez-Lopez, R.; Oyen, W.J.G.; Shore, N.; et al. Managing nonmetastatic castration-resistant prostate cancer. Eur. Urol. 2018, 75, 285-293. [CrossRef] [PubMed]

13. Francini, E.; Gray, K.P.; Xie, W.; Shaw, G.K.; Valença, L.; Bernard, B.; Albiges, L.; Harshman, L.C.; Kantoff, P.W.; Taplin, M.E.; et al. Time of metastatic disease presentation and volume of disease are prognostic for metastatic hormone sensitive prostate cancer (mHSPC). Prostate 2018, 78, 889-895. [CrossRef] [PubMed]

14. Sweeney, C.J.; Chen, Y.H.; Carducci, M.; Liu, G.; Jarrard, D.F.; Eisenberger, M.; Wong, Y.N.; Hahn, N.; Kohli, M.; Cooney, M.M.; et al. Chemohormonal therapy in metastatic hormone-sensitive prostate cancer. N. Eng. J. Med. 2015, 373, 737-746. [CrossRef] [PubMed] 
15. James, N.D.; Sydes, M.R.; Clarke, N.W.; Mason, M.D.; Dearnaley, D.P.; Spears, M.R.; Ritchie, A.W.; Parker, C.C.; Russell, J.M.; Attard, G.; et al. Addition of docetaxel, zoledronic acid, or both to first-line long-term hormone therapy in prostate cancer (STAMPEDE): Survival results from an adaptive, multiarm, multistage, platform randomised controlled trial. Lancet 2016, 387, 1163-1177. [CrossRef]

16. Fizazi, K.; Tran, N.; Fein, L.; Matsubara, N.; Rodriguez-Antolin, A.; Alekseev, B.Y.; Özgüroğlu, M.; Ye, D.; Feyerabend, S.; Protheroe, A.; et al. Abiraterone plus prednisone in metastatic, castration-sensitive prostate cancer. N. Engl. J. Med. 2017, 377, 352-360. [CrossRef]

17. Harshman, L.C.; Chen, Y.H.; Liu, G.; Carducci, M.A.; Jarrard, D.; Dreicer, R.; Hahn, N.; Garcia, J.A.; Hussain, M.; Shevrin, D.; et al. Seven-month prostate-specific antigen is prognostic in metastatic hormone-sensitive prostate cancer treated with androgen deprivation with or without docetaxel. J. Clin. Oncol. 2018, 36, 376-382. [CrossRef] [PubMed]

18. Chi, K.N.; Kheoh, T.; Ryan, C.J.; Molina, A.; Bellmunt, J.; Vogelzang, N.J.; Rathkopf, D.E.; Fizazi, K.; Kantoff, P.W.; Li, J.; et al. A prognostic index model for predicting overall survival in patients with metastatic castration-resistant prostate cancer treated with abiraterone acetate after docetaxel. Ann. Oncol. 2016, 27, 454-460. [CrossRef] [PubMed]

19. Halabi, S.; Small, E.J.; Kantoff, P.W.; Kattan, M.W.; Kaplan, E.B.; Dawson, N.A.; Levine, E.G.; Blumenstein, B.A.; Vogelzang, N.J. Prognostic model for predicting survival in men with hormone-refractory metastatic prostate cancer. J. Clin. Oncol. 2003, 21, 1232-1237. [CrossRef]

20. Halabi, S.; Lin, C.Y.; Small, E.J.; Armstrong, A.J.; Kaplan, E.B.; Petrylak, D.; Sternberg, C.N.; Shen, L.; Oudard, S.; de Bono, J.; et al. Prognostic model predicting metastatic castration-resistant prostate cancer survival in men treated with second-line chemotherapy. J. Natl. Cancer Inst. 2013, 105, 1729-1737. [CrossRef]

21. Ryan, C.J.; Smith, M.R.; de Bono, J.S.; Molina, A.; Logothetis, C.J.; de Souza, P.; Fizazi, K.; Mainwaring, P.; Piulats, J.M.; Ng, S.; et al. Abiraterone in metastatic prostate cancer without previous chemotherapy. N. Engl. J. Med. 2013, 368, 138-148. [CrossRef]

22. Beer, T.M.; Armstrong, A.J.; Rathkopf, D.E.; Loriot, Y.; Sternberg, C.N.; Higano, C.S.; Iversen, P.; Bhattacharya, S.; Carles, J.; Chowdhury, S.; et al. Enzalutamide in metastatic prostate cancer before chemotherapy. N. Engl. J. Med. 2014, 371, 424-433. [CrossRef] [PubMed]

23. Curtis, C.; Shah, S.P.; Chin, S.F. The genomic and transcriptomic architecture of 2000 breast tumors reveals novel subgroups. Nature 2012, 486, 346-352. [CrossRef] [PubMed]

24. Beltran, H.; Wyatt, A.W.; Chedgy, E.C.; Donoghue, A.; Annala, M.; Warner, E.W.; Beja, K.; Sigouros, M.; Mo, F.; Fazli, L.; et al. Impact of therapy on genomics and transcriptomics in high-risk prostate cancer treated with neoadjuvant docetaxel and androgen deprivation therapy. Clin. Cancer Res. 2017, 23, 6802-6811. [CrossRef] [PubMed]

25. Grasso, C.S.; Wu, Y.M.; Robinson, D.R.; Cao, X.; Dhanasekaran, S.M.; Khan, A.P.; Quist, M.J.; Jing, X.; Lonigro, R.J.; Brenner, J.C.; et al. The mutational landscape of lethal castration-resistant prostate cancer. Nature 2012, 487, 239-243. [CrossRef] [PubMed]

26. Wyatt, A.W.; Gleave, M.E. Targeting the adaptive molecular landscape of castration-resistant prostate cancer. EMBO Mol. Med. 2015, 7, 878-894. [CrossRef]

27. Mostaghel, E.A.; Nelson, P.S.; Lange, P.; Lin, D.W.; Taplin, M.E.; Balk, S.; Ellis, W.; Kantoff, P.; Marck, B.; Tamae, D.; et al. Targeted androgen pathway suppression in localized prostate cancer: A pilot study. J. Clin. Oncol. 2014, 32, 229-237. [CrossRef] [PubMed]

28. Taplin, M.E.; Montgomery, B.; Logothetis, C.J.; Bubley, G.J.; Richie, J.P.; Dalkin, B.L.; Sanda, M.G.; Davis, J.W.; Loda, M.; True, L.D.; et al. Intense androgen-deprivation therapy with abiraterone acetate plus leuprolide acetate in patients with localized high-risk prostate cancer: results of a randomized phase II neoadjuvant study. J. Clin. Oncol. 2014, 32, 3705-3715. [CrossRef]

29. Montgomery, B.; Tretiakova, M.S.; Joshua, A.M.; Gleave, M.E.; Fleshner, N.; Bubley, G.J.; Mostaghel, E.A.; Chi, K.N.; Lin, D.W.; Sanda, M.; et al. Neoadjuvant enzalutamide prior to prostatectomy. Clin. Cancer Res. 2017, 23, 2169-2176. [CrossRef]

30. Beltran, H.; Prandi, D.; Mosquera, J.M.; Benelli, M.; Puca, L.; Cyrta, J.; Marotz, C.; Giannopoulou, E.; Chakravarthi, B.V.; Varambally, S.; et al. Divergent clonal evolution of castration-resistant neuroendocrine prostate cancer. Nat. Med. 2016, 22, 298-305. [CrossRef] 
31. Ku, S.Y.; Rosario, S.; Wang, Y.; Mu, P.; Seshadri, M.; Goodrich, Z.W.; Goodrich, M.M.; Labbé, D.P.; Gomez, E.C.; Wang, J.; et al. Rb1 and Trp53 cooperate to suppress prostate cancer lineage plasticity, metastasis, and antiandrogen resistance. Science 2017, 355, 78-83. [CrossRef]

32. Zou, M.; Toivanen, R.; Mitrofanova, A.; Floch, N.; Hayati, S.; Sun, Y.; Le Magnen, C.; Chester, D.; Mostaghel, E.A.; Califano, A.; et al. Transdifferentiation as a mechanism of treatment resistance in a mouse model of castration-resistant prostate cancer. Cancer Discov. 2017, 7, 736-749. [CrossRef] [PubMed]

33. Akamatsu, S.; Wyatt, A.W.; Lin, D.; Lysakowski, S.; Zhang, F.; Kim, S.; Tse, C.; Wang, K.; Mo, F.; Haegert, A.; et al. The placental gene PEG10 promotes progression of neuroendocrine prostate cancer. Cell Rep. 2015, 12, 922-936. [CrossRef] [PubMed]

34. Lin, D.; Wyatt, A.W.; Xue, H.; Wang, Y.; Dong, X.; Haegert, A.; Wu, R.; Brahmbhatt, S.; Mo, F.; Jong, L.; et al. High fidelity patient-derived xenografts for accelerating prostate cancer discovery and drug development. Cancer Res. 2014, 74, 1272-1283. [CrossRef] [PubMed]

35. Davies, A.H.; Beltran, H.; Zoubeidi, A. Cellular plasticity and the neuroendocrine phenotype in prostate cancer. Nat. Rev. Urol. 2018, 15, 271-286. [CrossRef] [PubMed]

36. Sowalsky, A.G.; Ye, H.; Bhasin, M.; Van Allen, E.M.; Loda, M.; Lis, R.T.; Montaser-Kouhsari, L.; Calagua, C.; Ma, F.; Russo, J.W.; et al. Neoadjuvant-intensive androgen deprivation therapy selects for prostate tumor foci with diverse subclonal oncogenic alterations. Cancer Res. 2018, 78, 4716-4730. [CrossRef] [PubMed]

37. Varambally, S.; Yu, J.; Laxman, B. Integrative genomic and proteomic analysis of prostate cancer reveals signatures of metastatic progression. Cancer Cell 2005, 8, 393-406. [CrossRef]

38. Tomlins, S.A.; Mehra, R.; Rhodes, D.R. Integrative molecular concept modeling of prostate cancer progression. Nat. Genet. 2007, 39, 41-51. [CrossRef]

39. Taylor, B.S.; Schultz, N.; Hieronymus, H. Integrative genomic profiling of human prostate cancer. Cancer Cell 2010, 18, 11-22. [CrossRef]

40. Robinson, D.; Van Allen, E.M.; Wu, Y.M.; Schultz, N.; Lonigro, R.J.; Mosquera, J.M.; Montgomery, B.; Taplin, M.E.; Pritchard, C.C.; Attard, G.; et al. Integrative clinical genomics of advanced prostate cancer. Cell 2015, 162, 454. [CrossRef]

41. Barbieri, C.E.; Baca, S.C.; Lawrence, M.S.; Demichelis, F.; Blattner, M.; Theurillat, J.P.; White, T.A.; Stojanov, P.; Van Allen, E.; Stransky, N.; et al. Exome sequencing identifies recurrent SPOP, FOXA1 and MED12 mutations in prostate cancer. Nat. Genet. 2012, 44, 685-689. [CrossRef]

42. Espiritu, S.M.G.; Liu, L.Y.; Rubanova, Y.; Bhandari, V.; Holgersen, E.M.; Szyca, L.M.; Fox, N.S.; Chua, M.L.K.; Yamaguchi, T.N.; Heisler, L.E.; et al. The evolutionary landscape of localized prostate cancers drives clinical aggression. Cell 2018, 173, 1003-1013. [CrossRef] [PubMed]

43. Boutros, P.C.; Fraser, M.; Harding, N.J.; de Borja, R.; Trudel, D.; Lalonde, E.; Meng, A.; Hennings-Yeomans, P.H.; McPherson, A.; Sabelnykova, V.Y.; et al. Spatial genomic heterogeneity within localized, multifocal prostate cancer. Nat. Genet. 2015, 47, 736-745. [CrossRef] [PubMed]

44. Wei, L.; Wang, J.; Lampert, E.; Schlanger, S.; DePriest, A.D.; Hu, Q.; Gomez, E.C.; Murakam, M.; Glenn, S.T.; Conroy, J.; et al. Intratumoral and intertumoral genomic heterogeneity of multifocal localized prostate cancer impacts molecular classifications and genomic prognosticators. Eur. Urol. 2017, 71, 183-192. [CrossRef] [PubMed]

45. Cooper, C.S.; Eeles, R.; Wedge, D.C.; Van Loo, P.; Gundem, G.; Alexandrov, L.B.; Kremeyer, B.; Butler, A.; Lynch, A.G.; Camacho, N.; et al. Analysis of the genetic phylogeny of multifocal prostate cancer identifies multiple independent clonal expansions in neoplastic and morphologically normal prostate tissue. Nat. Genet. 2015, 47, 367-372. [CrossRef] [PubMed]

46. Beltran, H.; Eng, K.; Mosquera, J.M.; Sigaras, A.; Romanel, A.; Rennert, H.; Kossai, M.; Pauli, C.; Faltas, B.; Fontugne, J.; et al. Whole-exome sequencing of metastatic cancer and biomarkers of treatment response. JAMA Oncol. 2015, 1, 466-474. [CrossRef]

47. Carreira, S.; Romanel, A.; Goodall, J.; Grist, E.; Ferraldeschi, R.; Miranda, S.; Prandi, D.; Lorente, D.; Frenel, J.S.; Pezaro, C.; et al. Tumor clone dynamics in lethal prostate cancer. Sci. Transl. Med. 2014, 6, 254 ra125. [CrossRef]

48. Conteduca, V.; Zamarchi, R.; Rossi, E.; Condelli, V.; Troiani, L.; Aieta, M. Circulating tumor cells: Utopia or reality? Future Oncol. 2013, 9, 1337-1352. [CrossRef] 
49. Danila, D.C.; Heller, G.; Gignac, G.A.; Gonzalez-Espinoza, R.; Anand, A.; Tanaka, E.; Lilja, H.; Schwartz, L.; Larson, S.; Fleisher, M.; et al. Circulating tumor cell number and prognosis in progressive castration-resistant prostate cancer. Clin. Cancer Res. 2007, 13, 7053-7058. [CrossRef]

50. Scher, H.I.; Jia, X.; de Bono, J.S.; Fleisher, M.; Pienta, K.J.; Raghavan, D.; Heller, G. Circulating tumor cells as prognostic markers in progressive, castration-resistant prostate cancer: a reanalysis of IMMC38 trial data. Lancet Oncol. 2009, 10, 233-239. [CrossRef]

51. Goldkorn, A.; Ely, B.; Quinn, D.I.; Tangen, C.M.; Fink, L.M.; Xu, T.; Twardowski, P.; Van Veldhuizen, P.J.; Agarwal, N.; Carducci, M.A.; et al. Circulating tumor cell counts are prognostic of overall survival in SWOG S0421: A phase III trial of docetaxel with or without atrasentan for metastatic castration-resistant prostate cancer. J. Clin. Oncol. 2014, 32, 1136-1142. [CrossRef]

52. Scher, H.I.; Heller, G.; Molina, A.; Attard, G.; Danila, D.C.; Jia, X.; Peng, W.; Sandhu, S.K.; Olmos, D.; Riisnaes, R.; et al. Circulating tumor cell biomarker panel as an individual-level surrogate for survival in metastatic castration-resistant prostate cancer. J. Clin. Oncol. 2015, 33, 1348-1355. [CrossRef] [PubMed]

53. Lorente, D.; Olmos, D.; Mateo, J.; Bianchini, D.; Seed, G.; Fleisher, M.; Danila, D.C.; Flohr, P.; Crespo, M.; Figueiredo, I.; et al. Decline in circulating tumor cell count and treatment outcome in advanced prostate cancer. Eur. Urol. 2016, 70, 985-992. [CrossRef] [PubMed]

54. Lorente, D.; Olmos, D.; Mateo, J.; Dolling, D.; Bianchini, D.; Seed, G.; Flohr, P.; Crespo, M.; Figueiredo, I.; Miranda, S.; et al. Circulating tumor cell increase as a biomarker of disease progression in metastatic castration-resistant prostate cancer patients with low baseline CTC counts. Ann. Oncol. 2018, 29, 1554-1560. [PubMed]

55. Antonarakis, E.S.; Lu, C.; Wang, H.; Luber, B.; Nakazawa, M.; Roeser, J.C.; Chen, Y.; Mohammad, T.A.; Chen, Y.; Fedor, H.L.; et al. AR-V7 and resistance to enzalutamide and abiraterone in prostate cancer. N. Engl. J. Med. 2014, 371, 1028-1038. [CrossRef]

56. Antonarakis, E.S.; Lu, C.; Luber, B.; Wang, H.; Chen, Y.; Nakazawa, M.; Nadal, R.; Paller, C.J.; Denmeade, S.R.; Carducci, M.A.; et al. Androgen receptor splice variant 7 and efficacy of taxane chemotherapy in patients with metastatic castration-resistant prostate cancer. JAMA Oncol. 2015, 1, 582-591. [CrossRef]

57. Scher, H.I.; Lu, D.; Schreiber, N.A.; Louw, J.; Graf, R.P.; Vargas, H.A.; Johnson, A.; Jendrisak, A.; Bambury, R.; Danila, D.; et al. Association of AR-V7 on circulating tumor cells as a treatment-specific biomarker with outcomes and survival in castration-resistant prostate cancer. JAMA Oncol. 2016, 2, 1441-1449. [CrossRef]

58. Scher, H.I.; Graf, R.P.; Schreiber, N.A.; Jayaram, A.; Winquist, E.; McLaughlin, B.; Lu, D.; Fleisher, M.; Orr, S.; Lowes, L.; et al. Assessment of the validity of nuclear-localized androgen receptor splice variant 7 in circulating tumor cells as a predictive biomarker for castration-resistant prostate cancer. JAMA Oncol. 2018, 4, 1179-1186. [CrossRef]

59. Romanel, A.; Tandefelt, D.G.; Conteduca, V.; Jayaram, A.; Casiraghi, N.; Wetterskog, D.; Salvi, S.; Amadori, D.; Zafeiriou, Z.; Rescigno, P.; et al. Plasma AR and abiraterone-resistant prostate cancer. Sci. Transl. Med. 2015, 312, 312re10. [CrossRef]

60. Salvi, S.; Casadio, V.; Conteduca, V.; Burgio, S.L.; Menna, C.; Bianchi, E.; Rossi, L.; Carretta, E.; Masini, C.; Amadori, D.; et al. Circulating cell-free AR and CYP17A1 copy number variations may associate with outcome of metastatic castration-resistant prostate cancer patients treated with abiraterone. Br. J. Cancer 2015, 112, 1717-1724. [CrossRef]

61. Salvi, S.; Casadio, V.; Conteduca, V.; Lolli, C.; Gurioli, G.; Martignano, F.; Schepisi, G.; Testoni, S.; Scarpi, E.; Amadori, D.; et al. Circulating AR copy number and outcome to enzalutamide in docetaxel-treated metastatic castration-resistant prostate cancer. Oncotarget 2016, 7, 37839-37845. [CrossRef]

62. Azad, A.A.; Volik, S.V.; Wyatt, A.W.; Haegert, A.; Le Bihan, S.; Bell, R.H.; Anderson, S.A.; McConeghy, B.; Shukin, R.; Bazov, J.; et al. Androgen receptor gene aberrations in circulating cell-free DNA: Biomarkers of therapeutic resistance in castration-resistant prostate cancer. Clin. Cancer Res. 2015, 21, 2315-2324. [CrossRef] [PubMed]

63. Wyatt, A.W.; Azad, A.A.; Volik, S.V.; Annala, M.; Beja, K.; McConeghy, B.; Haegert, A.; Warner, E.W.; Mo, F.; Brahmbhatt, S.; et al. Genomic alterations in cell-free DNA and enzalutamide resistance in castration-resistant prostate cancer. JAMA Oncol. 2016, 2, 1598-1606. [CrossRef] [PubMed] 
64. Conteduca, V.; Wetterskog, D.; Sharabiani, M.T.A.; Grande, E.; Fernandez-Perez, M.P.; Jayaram, A.; Salvi, S.; Castellano, D.; Romanel, A.; Lolli, C.; et al. Androgen receptor gene status in plasma DNA associates with worse outcome on enzalutamide or abiraterone for castration-resistant prostate cancer: A multi-institution correlative biomarker study. Ann. Oncol. 2017, 28, 1508-1516. [CrossRef] [PubMed]

65. Annala, M.; Vandekerkhove, G.; Khalaf, D.; Taavitsainen, S.; Beja, K.; Warner, E.W.; Sunderland, K.; Kollmannsberger, C.; Eigl, B.J.; Finch, D.; et al. Circulating tumor DNA genomics correlate with resistance to abiraterone and enzalutamide in prostate cancer. Cancer Discov. 2018, 8, 444-457. [CrossRef] [PubMed]

66. Sugawara, T.; Lejeune, P.; Köhr, S.; Neuhaus, R.; Faus, H.; Gelato, K.A.; Busemann, M.; Cleve, A.; Lücking, U.; von Nussbaum, F.; et al. BAY 1024767 blocks androgen receptor mutants found in castration-resistant prostate cancer patients. Oncotarget 2016, 7, 6015-6028. [CrossRef]

67. Schwarzenbach, H.; Hoon, D.S.; Pantel, K. Cell-free nucleic acids as biomarkers in cancer patients. Nat. Rev. Cancer 2011, 11, 426-437. [CrossRef]

68. de Bono, J.S.; Logothetis, C.J.; Molina, A.; Fizazi, K.; North, S.; Chu, L.; Chi, K.N.; Jones, R.J.; Goodman, O.B. Jr.; Saad, F.; et al. Abiraterone and increased survival in metastatic prostate cancer. N. Engl. J. Med. 2011, 364, 1995-2005. [CrossRef]

69. Scher, H.I.; Fizazi, K.; Saad, F.; Taplin, M.E.; Sternberg, C.N.; Miller, K.; de Wit, R.; Mulders, P.; Chi, K.N.; Shore, N.D.; et al. Increased survival with enzalutamide in prostate cancer after chemotherapy. N. Engl. J. Med. 2012, 367, 1187-1197. [CrossRef]

70. Tannock, I.F.; de Wit, R.; Berry, W.R.; Horti, J.; Pluzanska, A.; Chi, K.N.; Oudard, S.; Théodore, C.; James, N.D.; Turesson, I.; et al. Docetaxel plus prednisone or mitoxantrone plus prednisone for advanced prostate cancer. N. Engl. J. Med. 2004, 351, 1502-1512. [CrossRef]

71. de Bono, J.S.; Oudard, S.; Ozguroglu, M.; Hansen, S.; Machiels, J.P.; Kocak, I.; Gravis, G.; Bodrogi, I.; Mackenzie, M.J.; Shen, L.; et al. Prednisone plus cabazitaxel or mitoxantrone for metastatic castration-resistant prostate cancer progressing after docetaxel treatment: A randomised open-label trial. Lancet 2010, 376, 1147-1154. [CrossRef]

72. Mateo, J.; Carreira, S.; Sandhu, S.; Miranda, S.; Mossop, H.; Perez-Lopez, R.; Nava Rodrigues, D.; Robinson, D.; Omlin, A.; Tunariu, N.; et al. DNA-repair defects and olaparib in metastatic prostate cancer. N. Engl. J. Med. 2015, 373, 1697-1708. [CrossRef] [PubMed]

73. de Bono, J.S.; De Giorgi, U.; Nava Rodrigues, D.; Massard, C.; Bracarda, S.; Font, A.; Arranz Arija, J.A.; Shih, K.C.; Radavoi, G.D.; Xu, N.; et al. Randomized Phase II Study of Akt blockade with or without ipatasertib in abiraterone-treated patients with metastatic prostate cancer with and without PTEN Loss. Clin. Cancer Res. 2018, 25, 928-936. [CrossRef] [PubMed]

74. Chi, K.N.; Thomas, S.; Agarwal, N.; Feng, F.; Attard, G.; Wyatt, A.W.; Gormley, M.; Ricci, D.S.; Lopez-Gitlitz, A.; Deprince, K.; et al. Androgen receptor (AR) aberrations in patients (Pts) with metastatic castration-sensitive prostate cancer (mCSPC) treated with apalutamide (APA) plus androgen deprivation therapy (ADT) in TITAN. Ann. Oncol. 2019. [CrossRef]

75. Watson, P.A.; Arora, V.K.; Sawyers, C.L. Emerging mechanisms of resistance to androgen receptor inhibitors in prostate cancer. Nat. Rev. Cancer 2015, 15, 701-711. [CrossRef] [PubMed]

76. Beltran, H.; Yelensky, R.; Frampton, G.M.; Park, K.; Downing, S.R.; MacDonald, T.Y.; Jarosz, M.; Lipson, D.; Tagawa, S.T.; Nanus, D.M.; et al. Targeted next-generation sequencing of advanced prostate cancer identifies potential therapeutic targets and disease heterogeneity. Eur. Urol. 2013, 63, 920-926. [CrossRef] [PubMed]

77. Taniguchi, K.; Uchida, J.; Nishino, K.; Kumagai, T.; Okuyama, T.; Okami, J.; Higashiyama, M.; Kodama, K.; Imamura, F.; Kato, K. Quantitative detection of EGFR mutations in circulating tumor DNA derived from lung adenocarcinomas. Clin. Cancer. Res. 2011, 17, 7808-7815. [CrossRef]

78. Asim, M.; Massie, C.E.; Orafidiya, F.; Pértega-Gomes, N.; Warren, A.Y.; Esmaeili, M.; Selth, L.A.; Zecchini, H.I.; Luko, K.; Qureshi, A.; et al. Choline kinase alpha as an androgen receptor chaperone and prostate cancer therapeutic target. J. Natl. Cancer Inst. 2015, 108. [CrossRef]

79. Conteduca, V.; Scarpi, E.; Caroli, P.; Salvi, S.; Lolli, C.; Burgio, S.L.; Menna, C.; Schepisi, G.; Testoni, S.; Gurioli, G.; et al. Circulating androgen receptor combined with 18F-fluorocholine PET/CT metabolic activity and outcome to androgen receptor signalling-directed therapies in castration-resistant prostate cancer. Sci. Rep. 2017, 7, 15541. [CrossRef] 
80. Conteduca, V.; Burgio, S.L.; Menna, C.; Carretta, E.; Rossi, L.; Bianchi, E.; Masini, C.; Amadori, D.; De Giorgi, U. Chromogranin $\mathrm{A}$ is a potential prognostic marker in prostate cancer patients treated with enzalutamide. Prostate 2014, 74, 1691-1696. [CrossRef]

81. Burgio, S.L.; Conteduca, V.; Menna, C.; Carretta, E.; Rossi, L.; Bianchi, E.; Kopf, B.; Fabbri, F.; Amadori, D.; De Giorgi, U. Chromogranin A predicts outcome in prostate cancer patients treated with abiraterone. Endocr. Relat. Cancer 2014, 21, 487-493. [CrossRef]

82. Conteduca, V.; Aieta, M.; Amadori, D.; De Giorgi, U. Neuroendocrine differentiation in prostate cancer: Current and emerging therapy strategies. Crit. Rev. Oncol. Hematol. 2014, 92, 11-24. [CrossRef] [PubMed]

83. Conteduca, V.; Oromendia, C.; Eng, K.W.; Bareja, R.; Sigouros, M.; Molina, A.; Faltas, B.M.; Sboner, A.; Mosquera, J.M.; Elemento, O.; et al. Clinical features of neuroendocrine prostate cancer. Eur. J. Cancer 2019, 121, 7-18. [CrossRef] [PubMed]

84. Conteduca, V.; Scarpi, E.; Salvi, S.; Casadio, V.; Lolli, C.; Gurioli, G.; Schepisi, G.; Wetterskog, D.; Farolfi, A.; Menna, C.; et al. Plasma androgen receptor and serum chromogranin A in advanced prostate cancer. Sci. Rep. 2018, 8, 15442. [CrossRef] [PubMed]

85. Thadani-Mulero, M.; Nanus, D.M.; Giannakakou, P. Androgen receptor on the move: Boarding the microtubule expressway to the nucleus. Cancer Res. 2012, 72, 4611-4615. [CrossRef]

86. Conteduca, V.; Jayaram, A.; Romero-Laorden, N.; Wetterskog, D.; Salvi, S.; Gurioli, G.; Scarpi, E.; Castro, E.; Marin-Aguilera, M.; Lolli, C.; et al. Plasma androgen receptor and docetaxel for metastatic castration-resistant prostate cancer. Eur. Urol. 2019, 75, 368-373. [CrossRef]

87. Conteduca, V.; Castro, E.; Wetterskog, D.; Scarpi, E.; Jayaram, A.; Romero-Laorden, N.; Olmos, D.; Gurioli, G.; Lolli, C.; Sáez, M.I.; et al. Plasma AR status and cabazitaxel in heavily treated metastatic castration-resistant prostate cancer. Eur. J. Cancer 2019, 116, 158-168. [CrossRef]

88. De Giorgi, U.; Severi, S.; Sarnelli, A.; Sansovini, M.; Monti, M.; Gurioli, G.; Nicolini, S.; Scarpi, E.; Casadei, C.; Conteduca, V.; et al. Circulating androgen receptor (AR) gene amplification and resistance to 177Lu-PSMA-617 in patients (pts) with metastatic castration-resistant prostate cancer (mCRPC): Results of a phase II clinical trial. J. Clin. Oncol 2019, 3. [CrossRef]

89. Clarke, N.; Wiechno, P.; Alekseev, B.; Sala, N.; Jones, R.; Kocak, I.; Chiuri, V.E.; Jassem, J.; Fléchon, A.; Redfern, C.; et al. Olaparib combined with abiraterone in patients with metastatic castration-resistant prostate cancer: A randomised, double-blind, placebo-controlled, phase 2 trial. Lancet Oncol. 2018, 19, 975-986. [CrossRef]

90. Rathkopf, D.E.; Smith, M.R.; Ryan, C.J.; Berry, W.R.; Shore, N.D.; Liu, G.; Higano, C.S.; Alumkal, J.J.; Hauke, R.; Tutrone, R.F.; et al. Androgen receptor mutations in patients with castration-resistant prostate cancer treated with apalutamide. Ann. Oncol. 2017, 28, 2264-2271. [CrossRef]

91. Borgmann, H.; Lallous, N.; Ozistanbullu, D.; Beraldi, E.; Paul, N.; Dalal, K.; Fazli, L.; Haferkamp, A.; Lejeune, P.; Cherkasov, A.; et al. Moving towards precision urologic oncology: Targeting enzalutamide-resistant prostate cancer and mutated forms of the androgen receptor using the novel inhibitor darolutamide (ODM-201). Eur. Urol. 2018, 73, 4-8. [CrossRef]

92. Sugawara, T.; Baumgart, S.J.; Nevedomskaya, E.; Reichert, K.; Steuber, H.; Lejeune, P.; Mumberg, D.; Haendler, B. Darolutamide is a potent androgen receptor antagonist with strong efficacy in prostate cancer models. Int. J. Cancer 2019, 145, 1382-1394. [CrossRef] [PubMed]

93. Conteduca, V.; Scarpi, E.; Matteucci, F.; Caroli, P.; Ravaglia, G.; Fantini, L.; Gurioli, G.; Schepisi, G.; Wetterskog, D.; Menna, C.; et al. Multimodal approach to outcome prediction in metastatic castration-resistant prostate cancer by integrating functional imaging and plasma DNA analysis. JCO Precis. Oncol. 2019, 3, 1-13. [CrossRef]

(C) 2019 by the authors. Licensee MDPI, Basel, Switzerland. This article is an open access article distributed under the terms and conditions of the Creative Commons Attribution (CC BY) license (http://creativecommons.org/licenses/by/4.0/). 